\title{
Microsporum gypseum infection in a horse with severe sweet itch
}

\author{
Microsporum gypseum-infectie bij een paard met erge zomereczeem
}

\author{
${ }^{1 *}$ F. Boyen, ${ }^{1 *}$ P. Van Rooij, ${ }^{1}$ L. Vanstallen, ${ }^{1}$ B. Flahou, ${ }^{1}$ F. Haesebrouck \\ ${ }^{1}$ Laboratory of Veterinary Bacteriology and Mycology, Department of Pathology, \\ Bacteriology and Avian Diseases, Faculty of Veterinary Medicine, Ghent University, \\ Salisburylaan 133, B-9820 Merelbeke, Belgium \\ *shared first authorship2 \\ filip.boyen@ugent.be
}

$\mathrm{A}_{\text {sismacr }}$

In a horse with severe sweet itch and a history of corticosteroid treatment for this disorder, a single, well-circumscribed and crusty white lesion was present on the thigh. The geophilic dermatophyte species $M$. gypseum was cultured from the lesion. The lesion was treated topically once a week with an enilconazole emulsion for four weeks. Full recovery was noted after two months. This case suggests that sweet itch combined with systemic corticosteroid treatment, may act as predisposing factor for dermatophyte infection. In addition, the importance of correct isolation and identification of the causal agent is highlighted.

\section{SAMENVATTING}

Bij een paard met erge zomereczeem en een voorgeschiedenis van corticosterö̈debehandeling voor deze aandoening, werd een welomschreven, cirkelvormig letsel met witte korstvorming opgemerkt. De geofiele schimmel Microsporum gypseum werd geïsoleerd uit het letsel, waarna een vier weken durende topicale behandeling met enilconazole werd gestart. Twee maanden na de behandeling was het letsel volledig hersteld. Deze case-report laat vermoeden dat zomereczeem in combinatie met systemische corticosteroïdebehandeling als risicofactor kan optreden voor een dermatofyteninfectie. Verder wordt het belang van een correcte staalname, isolatie en identificatie van de oorzakelijke kiem bediscussieerd.

\section{INTRODUCTION}

Dermatophytosis or ringworm is a superficial skin infection caused by dermatophytes. These filamentous fungi invade keratinized tissues, such as nails, claws, hair and stratum corneum of humans and animals causing mild to severe, localized or diffuse infections. Dermatophytes are classified in the genera Epidermophyton, Trichophyton and Microsporum. They can also be divided into three ecological groups according to their natural host or habitat. Humans are the natural host of anthropophilic dermatophytes. Zoophilic dermatophytes have one or more animal species as natural host, but as most of these fungi can also infect humans, they should be considered zoonotic. Geophilic dermatophytes have the soil as main reservoir, which may act as source of infection for animals and humans (De Hoog et al., 2000).
Dermatophytosis is one of the most common skin diseases in horses (Pilsworth et al., 2007). During an epidemiological survey carried out in Italy (Perugia), a prevalence up to $9 \%$ was found in riding horses (mainly T. equinum, no M. gypseum isolates). In all cases, infection was associated with clinical signs (Moretti et al., 1998). Main clinical features in horses include alopecia, erythema and crusting. Lesions are often restricted to skin areas in contact with the saddle or other horse tack (Chermette et al., 2008; Wobeser, 2015). In the present case report, dermatophytosis in a horse due to the geophilic Microsporum gypseum is described.

\section{CASE PRESENTATION}

An eight-year-old Friesian gelding presented in autumn 2015 with a single, well-circumscribed, slightly 
elevated, dry, crusted and alopecic lesion on the thigh (Figure 1). The horse had a history of extreme sweet itch, for which it had been treated with corticosteroids (dexamethasone, $30 \mathrm{mg} /$ daily per os) during summer. At the time the lesion appeared, the horse was still under corticosteroid treatment and was wearing an eczema blanket, which completely covered the lesion. Based on the clinical aspect of the lesions, dermatophytosis was suspected.

Prior to sampling, the skin lesion was superficially decontaminated with a 70\%-ethanol solution and airdried to reduce the number of contaminants. Hairs were plucked and scales were scraped from the margin of the lesion using a sterile scalpel blade. Skin scrapings and hairs were inoculated at several points on Dermasel agar (Oxoid, Basingstoke, UK), supplemented with penicillin $\mathrm{G}(1000 \mathrm{IU} / \mathrm{ml})$ and streptomycin sulphate $(1 \mathrm{mg} / \mathrm{ml})$. Plates were incubated at $25^{\circ} \mathrm{C}$ and checked daily for growth. To prevent overgrowth by saprobic fungi, suspected dermatophyte colonies were purified on Sabouraud dextrose agar (SDA) (Oxoid). The identification was deduced from macro- and microscopic features on SDA. Colonies were stellate, with a marked powdery aspect, cream-colored to cinnamon-tan with whitish aerial mycelium in the center of the colony and with a yellowish-buff to brownish verso (Figure 2). Microscopic examination of the purified culture revealed very abundant macroconidia and sparse microconidia (Figure 3). Macroconidia were septated, fusiform, thin- and rough-walled and arranged in dense clusters. Some macroconidia had a flagellated appendix (Figure 3A). Microconidia were sessile or stalked, smooth- and thin-walled and clavate (Figure 3B). Based on morphological features, the isolate was identified as M. gypseum. To confirm the diagnosis, the ITS1-5.8S-ITS2 ribosomal DNA region of the isolate was amplified using the panfungal primers ITS1 and ITS 4 [6] and sequenced. BLAST search in the ITS RefSeq database (NCBI) revealed a $100 \%$ sequence similarity with M. gypseum. Given the limited extent of the lesions, topical therapy was initiated with an enilconazol emulsion (Imaverol, Janssen Animal Health, Beerse, Belgium), once weekly, for four weeks. The lesion improved gradually and full recovery was achieved after two months.

\section{DISCUSSION}

In this report, a case of equine dermatophytosis due to the geophilic dermatophyte M. gypseum is described. The main etiological agent of dermatophytosis in horses is the zoophilic dermatophyte Trichophyton equinum, which is highly contagious among horses and may also infect humans (Chermette et al., 2008; White et al., 1990). Other zoophilic dermatophyte species, such as Microsporum canis (including the former Microsporum equinum) (De Hoog et al., 2000), Trichophyton mentagrophytes and Trichophyton verrucosum, are less frequently involved (Moretti

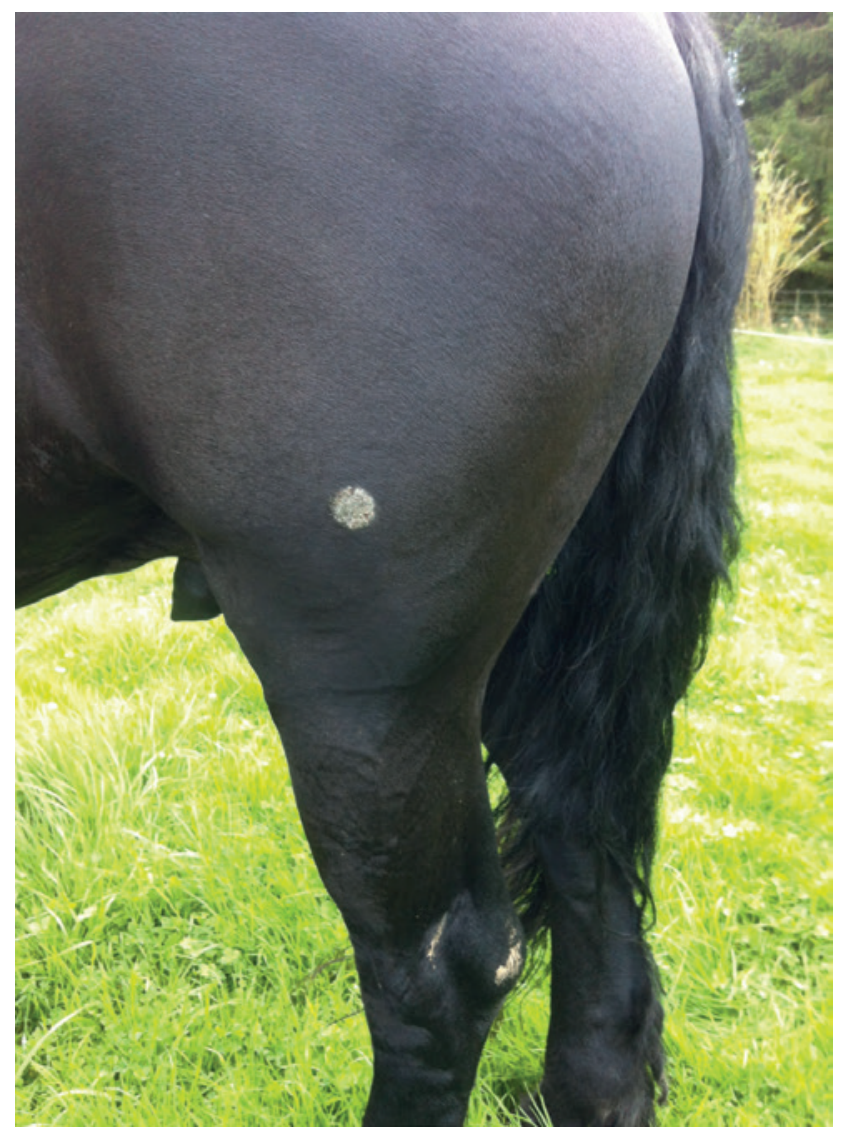

Figure 1. Clinical aspect of a Microsporum gypseum infection in a Friesian horse, which presented as a single well-circumscribed and crusty lesion on the thigh.

et al., 1998; Cabañes et al., 1997; et al., 2000; Khosravi and Mahmoudi, 2003). Hitherto, infection due to $M$. gypseum has only occasionally been reported in horses (Khosravi and Mahmoudi, 2003; Tanner, 1982; Chiers et al., 2003).

To the authors' knowledge, there is no evidence of transmission of $M$. gypseum infections between horses, even though this could be theoretically possible, for example by common use of saddle blankets. Although transmission to humans from animals cannot be entirely excluded (Chermette et al., 2008; Romano et al., 2000; Romano et al., 2009), ringworm due to $M$. gypseum is not considered zoonotic. As M. gypseum lives saprobically in the soil, the outdoor environment constitutes the main source of infection. The risk of infection is higher for horses that are not stalled, living outdoor (Chermette et al., 2008).

Dermatophyte infections in healthy horses are considered to be self-limiting (Chermette et al., 2008; Wobeser, 2015; Scott and Miller, 2011). However, treatment of active infection is appropriate to advance healing of the lesions and to reduce spread of the infective arthroconidia into the environment (Chermette et al., 2008; Wobeser, 2015). When tackling infections due to zoophilic dermatophytes, antimycotic therapy may also help to avoid spread of the infection to other animals and humans. 


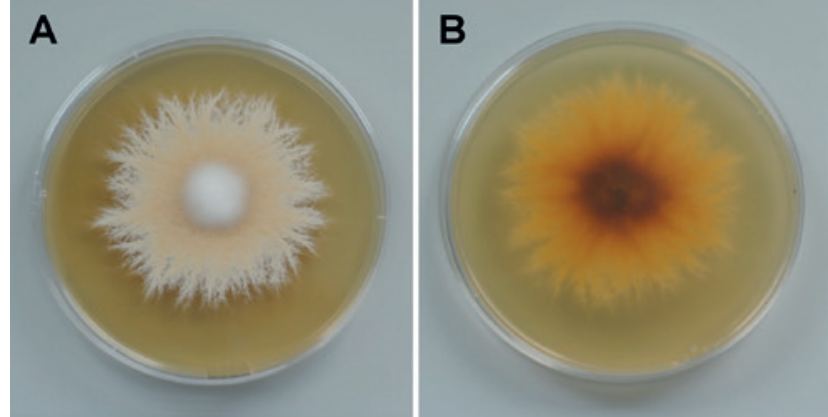

Figure 2. Macroscopical aspects of the purified Microsporum gypseum isolate, incubated on SDA for 7 days $25^{\circ} \mathrm{C}$; A. recto; B. verso.

In the present case, the combination of sweet itch and the use of immunosuppressive drugs may have acted as predisposing factors. Sweet itch is a chronic, recurrent, seasonal dermatitis in horses caused by an allergic reaction to the bite of Culicoides spp. and is therefore often referred to as insect bite hypersensitivity (Van Grevenhof et al., 2007). The symptoms include intense pruritus, and the scratching may result in skin lesions and secondary infections. As a rule, the mane and tail are affected. However, in horses with severe signs, lesions may be spread over the entire body (Halldorsdottir and Larsen, 1991; Björnsdottir et al., 2006). So far, no connection between dermatophyte infection and sweet itch has been reported in the literature. Only Scott and Miller (2011) have mentioned that skin damage caused by ectoparasites (e.g. lice and biting flies) is probably important in the establishment and spread of dermatophytosis. The use of immunosuppressive drugs such as glucocorticoids, on the contrary, is known to entail an increased risk of developing fungal infections, including dermatophytosis (Chermette et al., 2008; Scott and Miller, 2011; Van Rooij et al., 2012; Guillot, 2013; Miller et al., 2013). Glucocorticoids interfere with first-line immune defences, mainly by suppressing the function of macrophages and inhibiting lysozyme synthesis (Panarelli, 1994; Papich, 2013).

Infections due to $M$. gypseum in horses may be more common than generally thought. Many cases of dermatophytosis in horses are not reported and the causal agent is often not identified. Isolation and identification of the causal agent may prove challenging. For example, to ascertain the cause of a dermatophytosis, proper specimen collection is of the utmost importance. The equine hair coat is a source for bacteria, saprobic moulds and yeasts that may complicate the isolation of causal dermatophytes by their fast (over) growth (Scott and Miller, 2011). Therefore, it is important that lesions are disinfected with $70 \%$ ethanol to reduce the occurrence of contaminants. Furthermore, scales should be scraped off and/or hairs should be plucked (not clipped) from the margins of the lesions. Even though commercial PCR kits are available to rapidly identify certain dermatophytes, including $M$. gypseum, they are often limited to the detection of only one species. Correct identification of the causal agent may help to identify the source of infection and to estimate the risk the infection spreads to other animals or humans.

\section{CONCLUSIONS}

To the authors' knowledge, this is the first case to suggest that sweet itch in combination with systemic corticosteroid treatment may act as predisposing factor for the development of dermatophytosis. In this paper, the importance of correct isolation and identification of the causal agent is also highlighted.

\section{AVAILABILITY OF DATA AND MATERIALS}

The data supporting the authors' findings are contained within the manuscript. Sequences are available in the EMBL/Genbank/DDBJ repository (accession number: LN886514; http: http://www.ebi.ac.uk/ena/ data/view/LN886514). The M. gypseum isolate was deposited in the BCCM/IHEM repository (accession number: IHEM 26589).
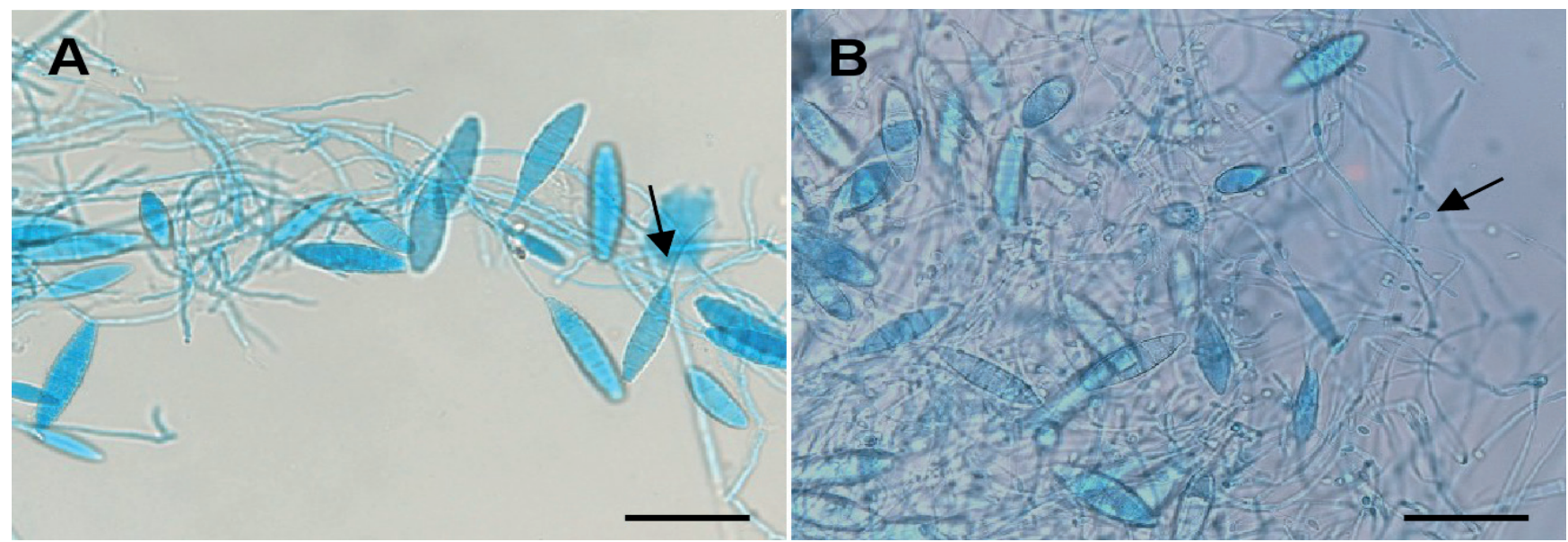

Figure 3. Microscopical morphology of the Microsporum gypseum isolate after purification and incubation on SDA at $25^{\circ} \mathrm{C}$ showing A. predominantly rough-walled, spindle-shaped macroconidia and a flagellated macroconidium (arrow) and B. sparse, club-shaped microconidia (arrow); scale bar: $50 \mu \mathrm{m}$ 


\section{ACKNOWLEDGEMENTS}

PVR was funded by Ghent University Special Research Fund (BOF13/PDO/130). BF was funded by Research Fund-Flanders (FWO) grant FWO14/ $\mathrm{PDO} / 067$.

\section{REFERENCES}

Björnsdottir S, Sigvaldadottir J, Broström H, Langvad B, Sigurosson A. (2006). Summer eczema in exported Icelandic horses: influence of environmental and genetic factors. Acta Veterinaria Scandinavica 48, 3.

Cabañes FJ. (2000). Dermatofitosis animales. Recientes avances. Revista Iberoamericana Micologia 17, 8-12.

Cabañes FJ, Abarca ML, Bragulat MR. (1997). Dermatophytes isolated from domestic animals in Barcelona, Spain. Mycopathologia 137, 107-113.

Chermette R, Ferreiro L, Guillot J. (2008). Dermatophytoses in animals. Mycopathologia 166, 385-405.

Chiers K, Decostere A, Devriese LA, Haesebrouck F. (2003). Bacteriological and mycological findings, and in vitro sensitivity of pathogenic Staphylococci in equine skin infections. Veterinary Record 1, 138-139.

De Hoog GS, Guarro J, Gené J, Figueras MJ (2000). Atlas of Clinical Fungi. Second edition, Utrecht, Reus, Centraal bureau voor schimmelcultures, Universitat Rovira i Virgili.

Guillot B. (2013). Effets indésirables cutanés des glucocorticoïdes. La Revue de Médecine Interne 34, 310-314.

Halldorsdottir S, Larsen HJ (1991). An epidemiological study of summer eczema in Icelandic horses in Norway. Equine Veterinary Journal 23, 296-299.

Khosravi AR, Mahmoudi M. (2003). Dermatophytes isolated from domestic animals in Iran. Mycoses 46, 222-225.

Miller WJ, Griffin C, Campbell K. (2013). Fungal and algal skin diseases. In: Miller WJ, Griffin C, Campbell K. (editors). Muller \& Kirk's Small Animal Dermatology. Seventh edition, St Louis, Saunders-Elsevier, p. 223-283.
Moretti A, Boncio L, Pasqual P, Piergili Fioretti D. (1998). Epidemiological aspects of dermatophyte infections in horses and cattle. Journal of Veterinary Medicine B. 45, 205-208.

Panarelli M, Holloway CD, Mulatero P, Fraser R, Kenyon CJ. (1994). Inhibition of lysozyme synthesis by dexamethasone in human mononuclear leukocytes: an index of glucocorticoid sensitivity. Journal of Clinical Endocrinology and Metabolism 78, 872-877.

Papich MG. (2013). Immunosuppressive drugs and cyclosporin. In: Riviere JE, Papich MG, (editors). Veterinary Pharmacology and Therapeutics. Ninth edition, Iowa, Wiley Blackwell, p.1233-1246.

Pilsworth RC, Knottenbelt D. (2007). Skin disease refresher. Equine Veterinary Education 19, 151-154.

Romano C, Asta F, Massai L. (2000). Tinea Incognito due to Microsporum gypseum in three children. Pediatric Dermatology 17, 41-44.

Romano C, Massai L, Gallo A, Fimiani M. (2009). Microsporum gypseum infection in the Siena area in 2005 2006. Mycoses 52, 67-71.

Scott DW, Miller WH. (2011). Equine Dermatology. Second edition, St. Louis, Elsevier-Saunders.

Tanner AC. (1982). Microsporum gypseum as the cause of ringworm in a horse. Veterinary Record 111, 396.

Van Grevenhof EM, Ducro B, Heuven HCM, Bijma P. (2007). Identification of environmental factors affecting the prevalence of insect bite hypersensitivity in Shetland ponies and Friesian horses in the Netherlands. Equine Veterinary Journal 9, 69-73.

Van Rooij P, Declercq J, Beguin H. (2012). Canine dermatophytosis caused by Trichophyton rubrum: an example of man-to-dog transmission. Mycoses 55, e15-17.

White TJ, Bruns T, Lee S, Taylor J. (2015). Amplification and direct sequencing of fungal ribosomal RNA genes for phylogenetics. In: Innis MA, Gelfand DH, Sninski JJ, White TJ (editors). PCR-protocols: a Guide to Methods and Applications. San Diego, Academic Press; 1990, p. 315-322.

Wobeser BK. (2015). Skin diseases in horses. Veterinary Clinics of North America - Equine Practice 31, 359-376. 